\title{
Evaluation of the Nipah epidemic containment and multisectoral involvement in Kerala using an appropriate management framework
}

\author{
Asma A. Rahim*, Sujina C. Muthukutty, Sabitha R. Jacob, Rini Ravindran, \\ Jayakrishnan Thayyil, Jayakrishnan Thavody
}

Department of Community Medicine, Government Medical College, Manjeri, Kerala, India

Received: 12 April 2020

Revised: 17 May 2020

Accepted: 18 May 2020

\section{*Correspondence:}

Dr. Asma A. Rahim,

E-mail: rahmaniyas@gmail.com

Copyright: (c) the author(s), publisher and licensee Medip Academy. This is an open-access article distributed under the terms of the Creative Commons Attribution Non-Commercial License, which permits unrestricted non-commercial use, distribution, and reproduction in any medium, provided the original work is properly cited.

\begin{abstract}
Kozhikode district of North Kerala, India witnessed an outbreak of Nipah virus (NiV) in the month of May 2018. Two adjacent districts were affected leaving 17 patients dead out of the 19 confirmed. United Nations and WHO lauded the expeditious response of the state's health system in the diagnosis and containment of the outbreak which was unprecedented. The authors being in the contact tracing and surveillance operation district team, had kept a record of timeline of events and actions at the state level, compiled the news clippings and tracked events. In the absence of an end-of-epidemic report for reference, these records served as a valuable tool for the present review. We used the Management science for health frame work tool ( $\mathrm{MSH}$ framework) to evaluate the district and state coordinated actions which helped in curbing the outbreak. Though NiV outbreak in South India (2018) had similar epidemiological features to previous disease outbreaks, it stands out as the one to be detected and contained in a short span of time. As health personnel working in the government medical college of an affected district and directly involved in contact tracing operations and containment measures, exploring and sharing, what worked and how, in the context of multidisciplinary response and recovery attempts of the outbreak in the state may be beneficial to public health personnel and policy makers. This management framework may be replicated in the national and international context, particularly in South East Asian region under threat of emerging viral infections like COVID-19, lacking specific epidemic management frameworks for outbreak response and containment.
\end{abstract}

Keywords: Evaluation, Kerala state, MSH framework, Nipah outbreak, Response, Recovery measures

\section{INTRODUCTION}

A 26 year old male got admitted with clinical features of encephalitis, tachycardia and hypertension, which is a highly improbable presentation at an NABH accredited private health facility at Kozhikode district of North Kerala, India on 13th May, 2018. Patients sibling had died 12 days ago at a government health facility with an inconclusive diagnosis. Based on the treating neurologist speculation that the symptoms of both siblings closely matched those of the patients affected in the 1998 Nipah outbreak in Malaysia, diagnostic samples were dispatched to Karnataka's Manipal Centre for Virus Research (MCVR), a Biosafety level -3 laboratory, and also to the National Institute of Virology, Pune (NIV). Confirmation came out in May 20th, 2018 as the first NiV outbreak in South India. As of 1st June 2018, Nipah claimed 21 lives out of 23 cases in the Kozhikode and Malappuram districts of Kerala, with a case fatality rate (CFR) of $88.9 \% .^{1}$ The majority of cases had history of visiting the Government health facility or being admitted into the facility. 
Nipah virus infection was first recognized in peninsular Malaysia (September 1998 to April 1999). Most patients had contact with sick pigs or close physical contact with Nipah virus infected patients and then presented primarily with encephalitis. Table 1 depicts the Nipah virus mortality and morbidity over the years 1998-2018. ${ }^{2}$ United Nations (UN) and World Health Organization (WHO) lauded the state government for the early diagnosis and efficient containment of Nipah within a limited time, which was unprecedented compared to previous outbreaks of encephalitis like illness in India.

Table 1: MSH checklist-representation from as many as possible sectors.

\begin{tabular}{|c|c|c|}
\hline Sectors & $\begin{array}{l}\text { Yes/ } \\
\text { No }\end{array}$ & Remarks \\
\hline $\begin{array}{l}\text { Public health } \\
\text { and medical } \\
\text { services }\end{array}$ & Yes & $\begin{array}{l}\text { District health personnel, } \\
\text { Specialists from } \\
\text { Departments of Medicine. } \\
\text { Pediatrics, Community } \\
\text { Medicine, Microbiology } \\
\text { from Government Medical } \\
\text { colleges. Kozhikode and } \\
\text { Manjeri }\end{array}$ \\
\hline $\begin{array}{l}\text { Public safety } \\
\text { and security }\end{array}$ & Yes & $\begin{array}{l}\text { District collector, Police } \\
\text { department }\end{array}$ \\
\hline Public works & No & \\
\hline Food security & Yes & Civil supplies officers \\
\hline Education & Yes & $\begin{array}{l}\text { District education officer } \\
\text { under Collectors supervision }\end{array}$ \\
\hline $\begin{array}{l}\text { Business and } \\
\text { commerce }\end{array}$ & Yes & $\begin{array}{l}\text { District Vyapari vyavasayi } \\
\text { representatives }\end{array}$ \\
\hline Finance & Yes & State finance officials \\
\hline $\begin{array}{l}\text { Logistics and } \\
\text { transportatio } \\
\text { n }\end{array}$ & Yes & $\begin{array}{l}\text { Ambulance, vehicles by } \\
\text { National health mission and } \\
\text { District Medical office }\end{array}$ \\
\hline $\begin{array}{l}\text { Communicati } \\
\text { ons } \\
\text { spokesperson } \\
\text { (s) }\end{array}$ & Yes & $\begin{array}{l}\text { Media, newspapers, Spokes } \\
\text { person from the DMO's } \\
\text { office }\end{array}$ \\
\hline $\begin{array}{l}\text { Telecommuni } \\
\text { cations and } \\
\text { IT }\end{array}$ & Yes & $\begin{array}{l}\text { Toll free helpline established } \\
\text { - with the contact number - } \\
\text { DISHA }\end{array}$ \\
\hline Civil society & Yes & $\begin{array}{l}\text { Representatives from Local } \\
\text { bodies }\end{array}$ \\
\hline $\begin{array}{l}\text { Humanitaria } \\
\text { n assistance } \\
\text { organizations }\end{array}$ & Yes & $\begin{array}{l}\text { Compassionate Kozhikode, } \\
\text { religious organizations }\end{array}$ \\
\hline $\begin{array}{l}\text { NGOs and } \\
\text { INGOs } \\
\text { operating in } \\
\text { the area }\end{array}$ & Yes & $\begin{array}{l}\text { Kerala Shastra Sahitya } \\
\text { Parishad }\end{array}$ \\
\hline
\end{tabular}

\section{METHODS}

The team from our institution was designated with contact tracing and surveillance operations by the state health department for Nipah in Malappuram district. All the authors were involved in case investigations, contact tracing, surveillance and reporting, counseling of contacts and families as well is in training of health workers and awareness generation. The team collaborated with the District administration to ensure strict vigil on the spread of the deadly Nipah virus in the community.

The authors had kept a record of timeline of events and actions at the state level, compiled the news clippings and tracked events, and being involved and entrusted with contact tracing operations. In the absence of an end-of-epidemic report for reference, these records served as a valuable tool for the present review.

Our team was particularly interested in evaluating the implementation of Nipah response and recovery plans at the local level. In search of a suitable epidemic response management frame work at the local level, the Management science for Health framework (MSH framework) came handy for this purpose as it had been successfully implemented for the EBOLA response plan. ${ }^{3}$ Study objective was to narrate the response and recovery attempts by the health system under the key headings discussed below and also evaluate the local involvement using the MSH framework.

\section{RESULTS}

\section{Disease surveillance system}

With a strong disease surveillance system in place, disease reporting unit at the government facility had already detected the primary case (first case that occurred in a naïve population and may go unrecognized) as viral encephalitis which did not yield conclusive laboratory results for the routine diagnostics. The primary case lay submerged skipping attention of clinicians and epidemiologists alike. The unusual presentations of the index case reporting two weeks later to the private health facility and the corroborative family history of similar illness prompted the treating team to review literature, collect samples and report the case to the district and state surveillance units. ${ }^{4}$

\section{Infection control precautions}

Though the government facility had an infection control policy, case investigations reveal that most of the infections were contracted by direct exposure to vomitus and respiratory droplets through cough from the diseased patients, similar to the Siliguri epidemic, Bangladesh and West Bengal. ${ }^{5,6}$ The key contact points were the Community health center, casualty and the CT scan waiting corridor of the government facility.

\section{Laboratory confirmation}

Though the primary case got missed, the index case diagnosed from the private hospital triggered the whole chain of events. District and state surveillance officers 
were informed and specimens transported to MCVR team, trained by the Centre for disease control, Atlanta. Samples were also transported as required to the NIV, Pune. Nationwide surveillance was called in to trace Nipah infections in other parts of the country.

\section{State response}

A team of entomologists and a medical team under the instruction of the District Medical officer, visited the home of the deceased on the morning of May 18 and executed routine AES control measures. ${ }^{7}$

\section{Center response}

Following notification a multi-disciplinary central team was formed, led by Director, National Centre for disease control (NCDC) along with epidemiologists and scientists from All India Institute of Medical sciences (AIIMS), Safdarjung Hospital, NIV Pune, Department of Animal Husbandry, National Institute of Immunology and Indian Council of Medical Research (ICMR). The team supported the state health authorities by monitoring and formulating guidelines for triage, treatment protocols, follow up, isolation and infection control. ${ }^{8}$

\section{Alert and preparedness}

By May 20th, an officer trained in EBOLA outbreak protocols instructed the State's doctors in infectioncontrol measures, isolating patients, using surgical masks and decontaminating surfaces. By May 22nd, results of 3 samples from Malappuram district were tested to be positive from MCR adding one more district under the scanner. A high-level emergency meeting with officials from concerned sectors chaired by the State health minister was convened. A medical alert was sounded across the state, with district collectors prepared to tackle any eventuality. The department also cancelled the leave of all doctors and health staff until further orders. Special wards and a 24-hour control room was opened to monitor and contain the outbreak. The public could resolve their doubts by dialling a toll free number-1056. A second task force team headed by the Director of Health services worked towards meeting emergencies. Ventilators were arranged at medical colleges and private hospitals. Patients from government hospitals would be shifted to private hospitals if required. The government also sought the help of the Indian Medical association and private hospitals to provide health personnel to tackle the emergencies if the need arose.

\section{Treatment protocols and drug procurement}

Apart from a clinical management protocol, Ribavirin was decided upon to be used in confirmed Nipah infections with the approval of DCGI. Efforts were also taken by the state ministry to procure monoclonal antibodies and guideline also suggested the use of Favipir. $^{9}$

\section{Multisectoral collaboration}

In the emergency task force meeting convened by the Health Minister and Director of Health services, representatives from several organizations participated. Responsibilities of each sector were defined. Administrative authorities of these institutions were to set up additional facilities and monitor the services.

\section{Animal husbandry}

Animal husbandry and forest department teams along with NIV/ICMR were deployed to collect samples from bats from the wells and the vicinity of the affected village, Chengaroth of Perambra Panchayat.

The Nipah link with the Pteropus bats was confirmed and established by NIV/ICMR, with $19.2 \%$ (10/52) of the bats testing positive. ${ }^{9}$ Health Promotion programs and collaboration with animal health services was in already in place in Kerala in the State and district health services and district administration. ${ }^{10}$

Table 2: Checklist evaluation of local coordinating committee activities.

\begin{tabular}{|c|c|c|c|c|}
\hline Task & Yes or No & Who is responsible? & Leadership & Remarks \\
\hline $\begin{array}{l}\text { Establish a local coordinating } \\
\text { committee }\end{array}$ & Yes & $\begin{array}{l}\text { District collectors of } \\
\text { Kozhikode and } \\
\text { Malappuram }\end{array}$ & $\begin{array}{l}\text { Health minister, } \\
\text { Director of Health } \\
\text { service }\end{array}$ & $\begin{array}{l}\text { Existing Rapid } \\
\text { response team }\end{array}$ \\
\hline $\begin{array}{l}\text { Obtain contact information of all } \\
\text { members }\end{array}$ & Yes & $\begin{array}{l}\text { District collector and } \\
\text { DMO }\end{array}$ & District Collector & \\
\hline $\begin{array}{l}\text { Designate a clear leader for the } \\
\text { LCC }\end{array}$ & Yes & DHS & $\begin{array}{l}\text { Minister of health } \\
\text { /Secretary to H } \\
\text { and FW }\end{array}$ & \\
\hline Determine the sector leads & Yes & District Collector & District Collector & \\
\hline $\begin{array}{l}\text { Develop a schedule for regular } \\
\text { meetings and a place to meet }\end{array}$ & Yes & District Collector & & \\
\hline
\end{tabular}


Table 3: Maintenance of essential services checklist.

\begin{tabular}{|c|c|c|}
\hline Task & $\begin{array}{l}\text { Yes } \\
\text { or No }\end{array}$ & $\begin{array}{l}\text { Who is } \\
\text { responsible? }\end{array}$ \\
\hline $\begin{array}{l}\text { Complete sector } \\
\text { resource maps }\end{array}$ & Yes & $\begin{array}{l}\text { District Collectors } \\
\text { of Kozhikode and } \\
\text { Malappuram }\end{array}$ \\
\hline $\begin{array}{l}\text { Identify sector } \\
\text { specific essential } \\
\text { services }\end{array}$ & Yes & $\begin{array}{l}\text { District collector } \\
\text { and DMO }\end{array}$ \\
\hline $\begin{array}{l}\text { Identify sector } \\
\text { specific non- essential } \\
\text { services }\end{array}$ & Yes & $\begin{array}{l}\text { District collector, } \\
\text { designated persons } \\
\text { from related sectors }\end{array}$ \\
\hline $\begin{array}{l}\text { Identify resource map } \\
\text { into one } \\
\text { comprehensive one }\end{array}$ & Yes & District Collector \\
\hline $\begin{array}{l}\text { Prioritise essential } \\
\text { services }\end{array}$ & Yes & District Collector \\
\hline $\begin{array}{l}\text { Identify which non } \\
\text { essential service to } \\
\text { suspend }\end{array}$ & Yes & $\begin{array}{l}\text { District collector, } \\
\text { designated persons } \\
\text { from related sectors }\end{array}$ \\
\hline $\begin{array}{l}\text { Develop a process to } \\
\text { use suspended non } \\
\text { essential services to } \\
\text { support essential } \\
\text { services }\end{array}$ & Yes & $\begin{array}{l}\text { District collector, } \\
\text { designated persons } \\
\text { from related sectors }\end{array}$ \\
\hline $\begin{array}{l}\text { Allocate resources to } \\
\text { the prioritized } \\
\text { essential services }\end{array}$ & Yes & District collector \\
\hline
\end{tabular}

\section{Social support}

Health minister and labor minister camped at the districts to lead the efforts. Door to door awareness programs were arranged in the case reported localities to clear apprehensions of the public. Throughout the month of Ramadan, Muslim communities in the affected districts of Kozhikode and Malappuram cooperated well by resorting to infection control measures such as social distancing of patients with Fever and related symptoms. The treatment expenses of Nipah patients were reimbursed by the government and food kits distributed to affected families in both districts.

\section{Contact tracing and surveillance}

Departments of Community Medicine of respective Government Medical colleges of the 2 districts carried out detailed field case investigation, contact tracing and follow up to 2000 potential contacts from Kozhikode and 239 from Malappuram. In Malappuram, contact tracing done by modifying the WHO Ebola contact tracing form helped us categorise and limit the contacts to 239 , thereby improving the efficiency.

We calculated the basic reproduction number from May 20th for the ensuing 4 week period as 0.4 , which indicated the epidemic to be dying out. The outbreak was contained and declared over on June 10, 2018.
Community were provided access through hotline numbers and ambulance facilities, for 21 days from the last day of exposure based on the WHO guidelines. ${ }^{11}$

Table 4: Actions to limiting the spread of disease.

\begin{tabular}{|lll|}
\hline Task & $\begin{array}{l}\text { Yes } \\
\text { or No }\end{array}$ & Who is responsible? \\
\hline $\begin{array}{l}\text { Inform the } \\
\text { public how to } \\
\text { avoid the illness } \\
\text { and where to } \\
\text { access care }\end{array}$ & Yes & $\begin{array}{l}\text { District Medical } \\
\text { Officer(DMO), Mass } \\
\text { media wing }\end{array}$ \\
\hline $\begin{array}{l}\text { Isolate Nipah } \\
\text { contacts from } \\
\text { the population }\end{array}$ & Yes & $\begin{array}{l}\text { DMOdicine personnel on } \\
\text { contact tracing }\end{array}$ \\
\hline $\begin{array}{l}\text { Identify } \\
\text { resources to } \\
\text { support home } \\
\text { isolation }\end{array}$ & Yes & $\begin{array}{l}\text { District collector, Local } \\
\text { body members }\end{array}$ \\
\hline $\begin{array}{l}\text { Train team to } \\
\text { handle dead } \\
\text { bodies and } \\
\text { disinfection of } \\
\text { homes ,vehicles } \\
\text { and public } \\
\text { places }\end{array}$ & Yes & $\begin{array}{l}\text { team, DMO, Infection } \\
\text { control committee of }\end{array}$ \\
\hline $\begin{array}{l}\text { Develop a } \\
\text { process to } \\
\text { request supplies } \\
\text { of PPE, body } \\
\text { bags, } \\
\text { disinfectants and } \\
\text { other needed } \\
\text { goods }\end{array}$ & & $\begin{array}{l}\text { Yovernment Medical } \\
\text { colleges, Microbiologists }\end{array}$ \\
\hline & & $\begin{array}{l}\text { DMO, Superintendents } \\
\text { of Medical colleges and } \\
\text { treating centres, }\end{array}$ \\
Dean/Principal \\
\hline
\end{tabular}

\section{Training}

Department of Microbiology was entrusted with the training of the infection control guidelines for health personnel in both districts. Special training was given to ambulance drivers for safe transport of sick patients to the isolation facility following standard precautions.

\section{Assessing local resources and needs}

Elected representatives of the local self-government in the affected areas were actively involved in response and recovery. Mortuary policies were formulated. Extreme care and standing operating procedures were laid down by the experts of NCDC for handling Nipah affected bodies during the cremation and burial. ${ }^{8}$

\section{Evaluation using a management frame work}

Management sciences for Health (MSH) formulated a replicable epidemic framework intended to support implementation of Ebola response plans at the local level. This framework is to help local areas implement the 
recommendations of International and National Ebola guidelines and plans and is adaptable to the Nipah affected areas. ${ }^{3}$

Table 5: Health sector triage checklist.

\begin{tabular}{|lll|}
\hline Task & $\begin{array}{l}\text { Yes or } \\
\text { No }\end{array}$ & $\begin{array}{l}\text { Who is } \\
\text { responsible ? }\end{array}$ \\
\hline $\begin{array}{l}\text { Identify key decision } \\
\text { makers }\end{array}$ & Yes & $\begin{array}{l}\text { District Collector, } \\
\text { DMO }\end{array}$ \\
\hline $\begin{array}{l}\text { Ensure all health } \\
\text { resources have been } \\
\text { mapped }\end{array}$ & Yes & DMO \\
\hline $\begin{array}{l}\text { Develop a plan for } \\
\text { IPAH settings of } \\
\text { care }\end{array}$ & Yes & $\begin{array}{l}\text { DMO, District } \\
\text { collector, local } \\
\text { body members, } \\
\text { Multidisciplinary } \\
\text { team }\end{array}$ \\
\hline $\begin{array}{l}\text { Develop a plan for } \\
\text { Nipah essential } \\
\text { services }\end{array}$ & Yes & $\begin{array}{l}\text { District Collector, } \\
\text { DMO (daily } \\
\text { review meetings) }\end{array}$ \\
\hline $\begin{array}{l}\text { Develop a plan to } \\
\text { support home care } \\
\text { if needed }\end{array}$ & No & $\begin{array}{l}\text { District Collector, } \\
\text { DMO, LSG } \\
\text { members }\end{array}$ \\
\hline $\begin{array}{l}\text { Develop a plan to } \\
\text { allocate resources to } \\
\text { support Nipah care } \\
\text { on an ongoing basis }\end{array}$ & Yes & $\begin{array}{l}\text { DMO, District } \\
\text { collector, Local } \\
\text { body members, } \\
\text { Multidisciplinary } \\
\text { team }\end{array}$ \\
\hline $\begin{array}{l}\text { Provide } \\
\text { psychosocial } \\
\text { support as needed to } \\
\text { health care workers, } \\
\text { families of cases and } \\
\text { the population }\end{array}$ & Partly & $\begin{array}{l}\text { yes } \\
\text { collector, Local } \\
\text { body members, } \\
\text { Public }\end{array}$ \\
\hline
\end{tabular}

The modules and worksheets in this document has been particularly helpful in evaluating Nipah response and control in the context of Kerala outbreak (Table 1-4). This checklist helped us evaluate the recovery and response measures in Kerala including representation from as many possible sectors, provision of essential services, limiting the spread of disease, health sector triage and recovery and resilience.

Our team from Medical college having collaborated with the District administration and health system, appointed by the health minister as the coordination agency for Case investigation and contact tracing operations in Malappuram district were involved in key areas such as Health sector triage and actions to limiting the spread of disease.

The findings from the checklist helped us to realize the enormity of the task undertaken at the District health system effectively supervised by the state health system, lead by the State minister of Health supported by the centre.
Strengths and limitations in recovery and response were as follows.

\section{Preepidemic phase}

Disease alert

Rapid disease alert was instituted with the health team visiting the area to investigate encephalitis prior to confirmation. Specimens were collected and send to reference lab without delay and initial control measures implemented within 24 hours.

\section{Epidemic phase}

Commendable work was done by the state health machinery in the following areas; Resource mobilization, coordination of prevention and control activities, active surveillance for Nipah, social and behavioural intervention programmes and clinical management of Nipah patients.

\section{Postepidemic}

Surveillance activities were resumed to preepidemic phase with a call to doctors and reporting officers to key up the activities. Official announcement to thank all stakeholders and announce the end of the epidemic was done by the state. The outbreak was contained and declared over on June 10, 2018.

\section{Limitations}

\section{Laboratory facilities}

In spite of a sensitive surveillance system, Nipah was missed due to lack of clinical suspicion in the primary case, inadequate lab diagnostic facilities and weak animal surveillance.

\section{Infection control practices}

Standard infection control practices were too weak, especially in government hospital settings.

Lack of awareness of public about potential risk behaviors for spread of infectious diseases, particularly hand washing.

\section{DISCUSSION}

This review has helped us identify areas that need to be strengthened for timely response and containment of emerging outbreaks in India, the latest being COVID-19 pandemic. The government facility missed the detection of primary case due to the absence of rigorous lab work up facilities and non-specific initial signs and symptoms of NiV infection. Strengthening the laboratory facilities by upgrading regional and zonal virology labs with Biosafety 4 facilities and establishing labs with RTPCR 
testing (Biosafety 2) should be given top priority. ${ }^{4}$ This should be planned in anticipation of outbreaks and not as a knee jerk response to outbreaks.

In a crowded tertiary hospital, with a fragmented referral system and crowd management, the possibility of slips in tight infection control protocols is exposed in this outbreak. In Kozhikode outbreak the deceased staff nurse who handled the primary case at a Community health centre, is presumed to have contracted infection while holding and disposing the emesis tray and handling the fluids of the primary case in the absence of droplet precautions. $^{4,7}$ There is a dire need for establishing a robust infection control system in place, practiced diligently.

The alert and preparedness of the District health system is evident from the rapid response of implementing routine AES control measures, in spite of lacking specific diagnosis. ${ }^{7}$ Rapidity at which centre responded in the face of this outbreak notification by the state is laudable. ${ }^{8}$ Multisectoral collaboration with community engagement is the highlight of the mitigation measures implemented to contain the outbreak as depicted in Tables 1-4.

MSH framework helped us in the evaluation of Nipah response plans at the local level, in the domains of multisector response coordination, maintanence of essential services, health sector triage and actions to limit the spread of NIPAH. ${ }^{3}$ This exercise highlighted the fact that along with national organizations steering the response to an outbreak, local, multi-sector leadership team is critical to the success of the response. As noted from the check list local context will be needed to identify vulnerable groups, address local customs and beliefs, identify resources and strategize locations for care, organize distribution of essential goods such as food, fuel and medical supplies. None of this can be done effectively without local knowledge and trusted local leaders. It is quite clear from the checklist how Nipah outbreak has affected multiple sectors in overlapping and interdependent ways and how well this has worked in Kerala.

For disseminating the best practices in pandemic response, our country should prioritise preparation, compilation of all reference documents for countries and the international community to learn and adapt from. Collaboration with wildlife mortality surveillance systems assumes importance in this context. Adopting a one health approach towards collaborative efforts of multiple disciplines working locally, nationally and globally, to attain optimal health for people, animals and our environment" should be the motto for prevention of exotic diseases, more so in the context of the COVID-19 pandemic.

\section{CONCLUSION}

The way Kerala has handled the Nipah virus outbreak holds crucial lessons for the rest of India. The rapid and comprehensive response mounted both by the central and state governments clearly highlights the importance of strong health systems and such a need has never been stronger than now, especially in view of the COVID-19 Pandemic. The lessons learnt from Nipah containment has primed Kerala state to tackle the present COVID-19 pandemic, the state having effectively crushed the pandemic curve and puts the spotlight on preparedness and strong health systems to effectively deal with such diseases.

\section{ACKNOWLEDGEMENTS}

Authors would like to thank Dr. M. P. Sasi, Principal, Government Medical College, Manjeri, Dr. Anupama S. R, Dr. Shimna Azeez, Dr. Anusree Nair, Dr. Muhammed Yasir, Dr. Shahul Hameed (Tutors, Senior Resident, Department of Community Medicine).

Funding: No funding sources

Conflict of interest: None declared

Ethical approval: Not required

\section{REFERENCES}

1. Sadanadan R, Arunkumar G, Laserson KF. Towards global health security: response to the May 2018 Nipah virus outbreak linked to Pteropus bats in Kerala. India BMJ Global Health. 2018;3:e001086.

2. Morbidity and mortality due to Nipah or Nipah-like virus encephalitis in WHO South-East Asia Region, 2001-2018" (PDF). Available at http://origin. searo.who.int/entity/emerging_diseases/links/morbid ity-and-mortality-nipah-sear-2001-2018.pdf. Accessed on 27 August 2018.

3. MSH framework for ebola response and recovery at the local level. Available at https://www.msh .org/sites/msh.org/ebola_framework_with_checklist s_10.05.14.pdf. Accessed on 12 March 2020.

4. Kumar AK, Kumar AS. Deadly Nipah outbreak in Kerala: lessons learned for the future. Indian J Crit Care Med. 2018;22:475-6.

5. Epidemiological investigations during Nipah outbreak Kozhikode and Malappuram districts, Kerala, India. Available at 2018. http://origin. searo.who.int/entity/research_policy/meetings/2.5_n ipah_nie_6aug18_final.pdf. Accessed on 20 August 2018.

6. Chadha MS, Comer JA, Lowe L. Nipah virusassociated encephalitis outbreak, Siliguri, India. Emerging Infect Dis. 2006;12(2):235-40.

7. Anatomy of an outbreak. The Hindu. Available at https:// www. the hindu. com/todays- paper/tpopinion/anatomy- of-an-outbreak/article24062331. Ece. Accessed on 8 August 2018. 
8. NIPAH virus disease guidelines. Ministry of Health and Family Welfare. Available at: https:// mohfw.gov.in/diseasealerts/nipah-virus-diseaseguidelines. Accessed on 7 August 2018.

9. Treatment guidelines for Kerala: Nipah virus disease. Available at http://ncdc.gov.in/index1.php? lang=1\&level=1\&sublinkid=238\&lid=242. Accessed on 5 August 2018.

10. Confirming virus in fruit bats difficult. Times of India. Available at https://timesofindia. indiatimes.com/city/kozhikode/confirming-virus-infruit-bats-difficult/articleshow/64360647.cms. Accessed on 10 August 2018.
11. World Health Organization. Implementation and management of contact tracing for Ebolavirus disease. Available at http://www. who.int/csr/resources/publications/ebola/contacttracing/en/. Accessed on 15 August 2018.

Cite this article as: Rahim AA, Muthukutty SC, Jacob SR, Ravindran R, Thayyil J, Thavody J.

Evaluation of the Nipah epidemic containment and multisectoral involvement in Kerala using an appropriate management framework. Int J Community Med Public Health 2020;7:2813-9. 